\title{
Regulasi Emosi dan Kelompok Teman Sebaya Pelaku Cyberbullying
}

\author{
Mutia Mawardah ${ }^{1}$, MG. Adiyanti ${ }^{2}$ \\ Fakultas Psikologi Universitas Gadjah Mada
}

\begin{abstract}
Technology that is getting more advanced has not only positive but also negative impacts. The number of cyberbullying cases keeps increasing as the use of information technology appliances grows. The subjects of this research were 7th and 8th graders of state junior high school "S", who were 12-14 years of age and had been using information technologies for at least 2 years. The result of this research showed that peer group conformity and emotional regulation are related to the tendency in them of becoming cyberbulliers as demonstrated by the $F$ value $=106.078$ and $p<0.01$ with an adjusted $R$-square value of 0.702 $(70.2 \%)$. Separately, peer group conformity in teenagers has a positive correlation and has an effect with partial correlation value $=0.603$ and with an effective contribution $=0.637$. The variable of emotional regulation separately has a negative correlation and has no effect with partial correlation value $=-0.092$.
\end{abstract}

Keywords: cyberbullying, emotional regulation, peer group conformity

Abstrak. Teknologi yang pesat, memiliki dampak yang positif, tetapi juga memiliki dampak negatif. Kasus cyberbullying akan terus meningkat seiring dengan kemajuan dalam penggunaan perangkat teknologi informasi. Subjek penelitian ini adalah siswa SMP Negeri "S" kelas VII dan VIII, usia 12-14 tahun, dan menggunakan teknologi informasi minimal 2 tahun. Hasil penelitian ini menunjukkan bahwa ada hubungan antara kelompok teman sebaya dan regulasi emosi dengan kecenderungan menjadi pelaku cyberbullying pada remaja yang ditunjukkan oleh nilai $F=106,078$ dan $p<0,01$, dengan nilai Adjust $R$ Square sebesar 0,702 (70,2\%). Secara terpisah kelompok teman sebaya memiliki hubungan positif dan memiliki pengaruh dengan nilai korelasi parsial=0,603 dan memiliki sumbangan efektif sebesar 0,637. Variabel regulasi emosi secara terpisah memiliki hubungan negatif dan tidak memiliki pengaruh dengan nilai korelasi parsial=-0,092.

Kata kunci: cyberbullying, regulasi emosi, kelompok teman sebaya

Remaja saat ini merepresentasikan generasi pertama yang mau tidak mau harus tumbuh dan berkembang dalam lingkungan di mana kemajuan teknologi informasi dan komunikasi merupakan bagian yang tidak terpisahkan dari kehidupan sehari-hari. Survei terbaru yang dilakukan pada remaja berusia 12-18 tahun

\footnotetext{
${ }^{1}$ Korespondensi mengenai isi artikel ini dapat dilakukan melalui: mutia.mawardah@gmail.com

2 Atau melalui: mg_adi@ugm.ac.id
}

menemukan bahwa 97\% dari mereka menggunakan internet paling tidak satu kali dalam seminggu (Raskauskas \& Stoltz, 2007). Para remaja juga menggunakan perangkat elektronik lainnya seperti telepon selular (ponsel) sebagai media untuk berkomunikasi dengan teman sebaya.

Penggunaan teknologi komunikasi seperti internet dan telepon seluler (ponsel) telah meningkat dan terus meningkat 
(Beran \& Li, 2005; Li, 2007). Meskipun teknologi komunikasi bermanfaat untuk keperluan siswa dalam belajar, namun tidak menutup kemungkinan media tersebut memiliki dampak negatif seperti cyberbullying (Cochrane, 2008).

William (2012) menyatakan bahwa ada beberapa hal yang dapat disimpulkan tentang perkembangan teknologi informasi dengan remaja, yaitu; (1) Remaja berevolusi dengan perkembangan teknologi yang signifikan, remaja tidak bisa lepas dari ponselnya yang berisi media sosial seperti facebook dan twitter; (2) Teknologi meningkatkan kehidupan sehari-hari remaja dengan berbagai macam cara, dengan berhubungan dengan siapapun tanpa terbatas ruang dan waktu; (3) Kemajuan teknologi yang semakin berkembang dan canggih, memberikan manfaat yang tidak terbatas sehingga memunculkan berbagai dampak yang negatif jika tanpa adanya pengawasan, seperti predator online, pornografi pada anak, dan pencurian identitas; (4) Dampak negatif lainnya yang sangat mendominasi kemajuan teknologi informasi adalah cybersex dan cyberbullying; (5) Penyusunan undangundang teknologi informasi yang ditujukan kepada pihak-pihak yang melakukann tindak kriminalisasi (cybercrime); (6) Undang-undang yang dibuat mengalami pelanggaran hak anak yang di bawah umur, karena menghambat kebebasan berekspresi. Sehingga menjadi hak dan kewajiban orangtua untuk mengarahkan pendidikan anak-anak mereka.

Kasus cyberbullying marak dibicarakan di media beberapa tahun terakhir, di Amerika beberapa orang remaja memilih bunuh diri akibat cyberbullying. Kasus yang terkenal adalah kasus Megan Meier yang memilih menggantung dirinya di kamar akibat kekerasan dan pelecehan verbal yang dialaminya melalui account pribadinya di MySpace. Kemudian Tyler Clementi, remaja berbakat yang terjun dari jembatan George Washington di Manhattan akibat teman sekamarnya tanpa sepengetahuannya mengekspos video aktivitas pribadinya dengan pasangan gay-nya melalui fasilitas live-streaming.

Di Jepang, survei yang dilakukan oleh Dewan Pendidikan di wilayah Hyogo, menunjukkan hasil survei bahwa $10 \%$ siswa sekolah menengah di Jepang menga$\mathrm{ku}$ pernah menerima ancaman melalui email, situs atau blog. Seorang siswa 18 tahun di Kobe, Jepang, melakukan bunuh diri setelah teman sekelasnya memajang foto tidak senonohnya di situs dan mengirim email pemerasan. Kementerian Pendidikan di Jepang melakukan evaluasi terhadap data kasus bunuh diri remaja selama 1999-2005. Sebanyak 16 kasus diselidiki ulang karena diduga terkait dengan bullying. Praktik bullying yang kian marak dilakukan lewat media elektronik, terutama telepon selular yang terhubung dengan internet, seperti ancaman, ledekan, dan kekerasan psikologis lainnya dapat diterima dengan mudah oleh korban di mana dan kapan saja. Markoto adalah remaja asal Jepang, dia mengaku sering diteror dengan email berisi ancaman, fotonya sering dijadikan bahan ejekan, bahkan banyak respon yang menyuruhnya mengakhiri hidupnya. Sehingga Markoto memutuskan untuk tidak pergi ke sekolah, menderita anorexia dan dua kali mencoba bunuh diri (Wahyu, 2012).

Beberapa survei yang dilakukan di Amerika Serikat, yaitu The American Justice Departemen Suicide menyatakan bahwa setidaknya satu dari empat orang siswa sekolah di seluruh Amerika Serikat pernah di-bully oleh temannya sendiri. Kemudian hasil penelitian menunjukkan bahwa bunuh diri adalah penyebab kematian terbesar di Amerika Serikat, yaitu 4.400 kasus 
per tahun. Dan penyebab terbesarnya adalah karena depresi akibat bullying (Ericson, 2001).

Bullying memiliki beberapa bentuk, salah satunya yaitu cyberbullying. Cyberbullying bisa diartikan sebagai pencemaran nama baik dalam bentuk teks atau gambar (termasuk foto dan video) melalui internet, ponsel, atau media elektronik lain. Semakin maraknya pengguna social networking seperti facebook, friendster, twitter dan sebagainya membuat banyak orang membuka informasinya. Informasi-informasi pribadi jika dimanfaatkan oleh orang yang tidak bertanggung jawab bisa disalahgunakan (Agatson, Kowalski, \& Limber, 2007).

Thompson (Kostiuk \& Gregory, 2002) menggambarkan regulasi emosi sebagai kemampuan merespon proses-proses ekstrinsik dan intrinsik untuk memonitor, mengevaluasi, dan memodifikasi reaksi emosi yang intensif dan menetap untuk mencapai suatu tujuan. Ini berarti apabila seseorang mampu mengelola emosinya secara efektif, maka ia akan memiliki daya tahan yang baik dalam menghadapi masalah.

\section{Bullying}

Berthold dan Hoover (2000) berpendapat bahwa perilaku agresi yang dialami pada masa kecil merupakan manifestasi dari gaya hidup yang dikembangkan oleh orangtua dan terus berlanjut hingga masa remaja dan dewasa. Olweus dan Alsaker (dalam Berthold \& Hoover, 2000) juga mengemukakan bahwa penindasan adalah perilaku anti-sosial yang dilakukan oleh pelajar dan perilaku ini dapat menimbulkan risiko di lingkungan sekolah.

Bullying adalah perilaku agresif yang dimaksudkan untuk menyakiti atau mengganggu orang lain, hal ini terjadi secara berulang-ulang dari waktu ke waktu, dan melibatkan ketidakseimbangan kekuatan sehingga orang yang lebih kuat atau kelompok dapat mengganggu individu atau kelompok yang kurang kuat. Perilaku agresif ini berisi ketidakseimbangan kekuasaan baik secara fisik atau secara psikologis (Camfiled, 2006; Nansel, Overpeck, Pilla, Ruan, Simons-Morton, \& Scheidt, 2001).

Fokus penelitian bullying lebih banyak pada fisik dan perilaku agresif secara verbal (Olweus, 1994; Prinstein, Boergers, \& Vernberg, 2001). Konsep bullying dan penipuan ini berubah mengikuti perkembangan zaman, seperti terdapat agresi yang dilakukan secara sembunyi-sembunyi seperti bergosip atau menyebarkan rumor tentang teman sebaya sendiri atau bukan dari kelompok teman sebayanya (Crick \& Gropeter, 1995).

\section{Cyberbullying}

Cyberbullying adalah bentuk bullying yang terjadi ketika seseorang atau beberapa siswa menggunakan teknologi informasi dan komunikasi seperti email, ponsel atau pager, pesan teks, pesan singkat, website pribadi, situs jejaring sosial (misalnya facebook, twitter, plurk, dan lain-lain), dan game online, untuk digunakan secara sengaja, berulang-ulang dan perilaku yang tidak ramah yang dimaksudkan untuk merugikan orang lain (Belsey, 2007; Lines, 2007).

Salah satu faktor terpenting yang mempengaruhi praktik cyberbullying, yaitu karena bersifat anonimitas, sehingga pela$\mathrm{ku}$ mampu melecehkan atau menggangu korban selama 24 jam. Anonimitas yang terdapat dalam setiap model komunikasi elektronik tidak hanya menyamarkan identitas namun dapat mengurangi akuntabilitas sosial, sehingga memudahkan pengguna untuk terlibat dalam permusuhan, tindakan agresif (Li, 2007). Kemudahan teknologi memungkinkan pelaku dapat 
menganggu korban kapan saja dan di mana saja (David-Ferdon \& Hertz, 2007).

Sangat sedikit yang mengetahui bagaimana risiko secara psikososial dalam keterlibatan baik pelaku maupun korban dalam praktik cyberbullying. Beberapa hasil penelitian menunjukkan bahwa, terdapat kemiripan antara bullying secara langsung dengan cyberbullying. Ada hubungan kuat antara cyberbullying dan ketidakmampuan menyesuaikan diri secara psikososial baik pelaku dan korbannya (Finkelhor, Mitchell, \& Wolak, 2006; Williams, Cheung, \& Choi, 2000; Ybarra \& Mitchell, 2004a; Ybarra, Alexander, \& Mitchell, 2005).

\section{Kelompok Teman Sebaya}

Konformitas terjadi dalam beberapa bentuk dan mempengaruhi aspek-aspek kehidupan remaja. Seseorang menampilkan perilaku tertentu karena setiap orang lain menampilkan perilaku tersebut biasanya dapat disebut dengan konformitas. Konformitas dijelaskan dengan sudut pandang yang berbeda-beda. Menurut Brehm dan Kassin (1993) mendefinisikan bahwa konformitas sebagai tendensi manusia untuk merubah persepsi, opini atau perilaku dengan cara yang konsisten dengan norma kelompok.

Aspek-aspek konformitas yang dikemukakan oleh Harrold Kelly (Stephan \& Stephan, 1985) dibagi menjadi dua aspek konformitas, yaitu; (a) Aspek Normatif yaitu pengaruh dari kelompok yang menyebabkan seseorang individu berperilaku conform karena didasarkan pada keinginan untuk dapat diterima oleh kelompok; (b) Aspek Informatif, yaitu pengaruh dari kelompok yang menyebabkan seseorang individu dapat berperilaku conform karena didasarkan pada keinginan dan kebutuhan untuk memperoleh informasi yang be- nar dan akurat tentang realitas dari orang lain.

\section{Regulasi Emosi}

Kemampuan mengekspresikan emosi yang dilakukan baik secara lisan maupun tulisan dapat membantu meningkatkan kesehatan, kesejahteraan psikologis dan fungsi fisik pada seseorang saat menghadapi peristiwa traumatik dalam hidupnya dan membantu mengatasi distres psikologis (Greenberg \& Stone, 1992; Mendolia \& Kleck, 1993; Strobee, Stroebe, Schut, Zech, \& Bout, 2002).

Aspek-aspek yang telah diuraikan dapat disimpulkan, bahwa aspek-aspek regulasi emosi adalah sebagai berikut; (1) Pemantauan, yaitu kemampuan ini berhubungan dengan bagaimana individu tersebut membuat suatu penetapan akan langkah apa yang akan digunakan untuk menghadapi segala bentuk emosi dan pikirannya (Garber \& Dodge, 2004) sehingga dapat lebih dengan jelas memantau emosi yang sedang dihadapi (Thompson dalam Kostiuk \& Gregory, 2002); (2) Penilaian, individu memberikan penilaian baik itu positif dan negatif atas segala peristiwa yang dihadapi sesuai dengan pengetahuan yang dimilikinya dan bagaimana menggunakan pengetahuannya tersebut untuk menghasilkan apa yang menjadi harapannya Thompson (Kostiuk \& Gregory, 2002). Penilaian positif dapat mengelola emosi secara baik, sehingga terhindar dari pengaruh-pengaruh emosi negatif yang membuat individu dapat bertindak diluar harapannya (Garber \& Dodge, 2004); (3) Pengubahan, yaitu perubahan emosi ke arah yang lebih baik dengan mengubah pengaruh negatif yang masuk menjadi suatu dorongan dalam diri agar menjadi individu dengan motivasi perubahan ke arah yang positif Thompson (Kostiuk \& Gregory, 2002), dan kemudian 
diterapkan dalam perilaku atas respon yang dipilihnya (Garber \& Dodge, 2004).

Tujuan penelitian ini adalah untuk mengetahui secara empiris hubungan kelompok teman sebaya dan regulasi emosi dengan kecenderungan menjadi pelaku cyberbullying pada remaja. Sedangkan manfaat yang diharapkan dari penelitian ini adalah; (1) Memberikan data empiris tentang hubungan kelompok teman sebaya dan regulasi emosi dengan kecenderungan menjadi pelaku cyberbullying pada remaja. Sebagai sumbangan pemikiran bagi ilmu pengetahuan dan khususnya psikologi serta sebagai bahan kajian bagi pihak-pihak yang tertarik meneliti tentang cyberbullying; (2) Hasil penelitian ini diharapkan dapat memberikan informasi tentang pentingnya kelompok teman sebaya yang positif dan kemampuan dalam meregulasi emosi pada masa remaja. Kelompok teman sebaya yang positif dapat diarahkan dengan dukungan dan peran serta orangtua dan guru, sehingga praktik cyberbullying dapat diminimalisir intensitasnya oleh remaja.

\section{Hipotesis Penelitian}

Hipotesis Mayor: "Ada hubungan antara kelompok teman sebaya dan regulasi emosi dengan kecenderungan menjadi pelaku cyberbullying pada remaja".

Hipotesis Minor: (1) "Ada hubungan positif antara kelompok teman sebaya dengan kecenderungan menjadi pelaku cyberbullying"; (2) "Ada hubungan negatif antara regulasi emosi dengan kecenderungan menjadi pelaku cyberbullying pada remaja."

\section{Metode}

Variabel-variabel dalam penelitian ini terdiri dari variabel tergantung yaitu kecenderungan menjadi pelaku cyberbullying dan variabel bebas yaitu kelompok teman sebaya dan regulasi emosi. Subjek yang digunakan berjumlah 90 orang dan memiliki ciri-ciri, rentang usia 12-14 tahun dan sudah menggunakan teknologi informasi minimal selama dua tahun.

Data penelitian dikumpulkan dengan menggunakan tiga alat ukur yaitu: (1) Skala Kecenderungan Menjadi Pelaku Cyberbullying (2) Skala Kelompok Teman Sebaya dan (3) Skala Regulasi Emosi. Pada skala kecenderungan menjadi pelaku cyberbullying yang berjumlah 50 aitem dengan subjek penelitian 60 orang, diperoleh hasil koefisien reliabilitas sebesar 0,969 dengan jumlah 47 aitem yang sahih. Sebaran nomor aitem yang layak dan yang gugur dapat dilihat pada Tabel 1.

Sedangkan pada skala kelompok teman sebaya yang berjumlah 48 aitem dengan subjek penelitian berjumlah 60 orang, diperoleh hasil koefisien reliabilitas sebesar 0,955 dengan jumlah 43 aitem yang sahih sedangkan sebaran nomor aitem yang layak dan yang gugur terlihat pada Tabel 2.

Tabel 1

Sebaran Skala Kecenderungan Menjadi Pelaku Cyberbullying Setelah Uji Coba

\begin{tabular}{llc}
\hline \multicolumn{1}{c}{ Aspek } & \multicolumn{1}{c}{ Nomor Butir } & Jumlah \\
\hline Intimidasi & $1,2,3,4,5,6,7,8,9,10,(26),(27), 28,(29), 30,31,32,33,34,35$ & 17 \\
Power & $11,12,13,14,15,16,17,36,37,38,39,40,41,42$ & 14 \\
Kontinuitas & $18,19,20,21,22,23,24,25,43,44,45,46,47,48,49,50$ & 16 \\
\hline & Total aitem & 47 \\
\hline
\end{tabular}

Catatan : angka dalam kurung (..) adalah butir yang gugur 
Tabel 2

Sebaran Skala Kelompok Teman Sebaya Setelah Uji Coba

\begin{tabular}{|c|c|c|}
\hline Aspek & Nomor Butir & Jumlah \\
\hline Normatif & $\begin{array}{l}1,2,3,4,5,6,7,8,9,10,(11), 12,13,14,(26), 27,28,29,30,31, \\
32,33,34,35,36,37\end{array}$ & 24 \\
\hline Informatif & $\begin{array}{l}15,16,(17), 18,19,20,21,22,23,24,25,38,39,40,(41),(42) \\
43,44,45,46,47,48\end{array}$ & 19 \\
\hline & Total aitem & 43 \\
\hline
\end{tabular}

Catatan : angka dalam kurung (..) adalah butir yang gugur

Dan pada skala regulasi emosi yang berjumlah 25 aitem dengan subjek penelitian berjumlah 60 orang diperoleh koefisien reliabilitas sebesar 0,892 dengan jumlah 22 aitem yang sahih. Sebaran nomor aitem yang layak dan yang gugur dapat dilihat pada Tabel 3.

Data yang terkumpul dianalisis dengan menggunakan teknik regresi berganda, untuk mengetahui hubungan antara dua variabel dan satu variabel tergantung (kelompok teman sebaya dan regulasi emosi sebagai variabel bebas dan kecenderungan pelaku cyberbullying sebagai variabel tergantung). Untuk pengolahan data, perhitungan ini dilakukan dengan menggunakan program SPSS-17 for windows.

Dalam melihat hasil analisis data regresi berganda, pengujian hipotesis mayor dilihat dari tabel model summary dan tabel anova. Untuk pengujian hipotesis minor, yang menunjukkan hubungan antar variabel penelitian dilihat dari tabel correlations dengan melihat nilai korelasi pearson dan untuk menunjukkan pengaruh antar varia- bel penelitian dilihat dari tabel koefisien dengan melihat nilai korelasi parsial.

\section{H a s i 1}

Penelitian ini membahas tentang hubungan antara kelompok teman sebaya dan regulasi emosi dengan kecenderungan menjadi pelaku cyberbullying, deskripsi data kecenderungan menjadi pelaku cyberbullying pada penelitian ini menunjukkan rata-rata tingkat kecenderungan menjadi pelaku cyberbullying subjek berada dalam kategori tinggi, yaitu sebanyak 43,3\% (39 orang) dari total keseluruhan subjek. Sedangkan kelompok teman sebaya pada penelitian ini menunjukkan rata-rata tingkat kelompok teman sebaya subjek berada dalam kategori sedang, yaitu 37,8 (34 orang) dari total keseluruhan subjek. Regulasi emosi pada penelitian ini menunjukkan rata-rata tingkat regulasi emosi subjek berada dalam kategori sangat rendah, yaitu sebanyak $28,8 \%$ (26 orang) dari total keseluruhan subjek.

Tabel 3

Sebaran Skala Regulasi Emosi Setelah Uji Coba

\begin{tabular}{llc}
\hline \multicolumn{1}{c}{ Aspek } & \multicolumn{1}{c}{ Nomor Butir } & Jumlah \\
\hline Pemantauan & $1,2,3,4,14,15,16$ & 7 \\
Penilaian & $5,6,7,8,17,18,19,20$ & 8 \\
Pengubahan & $9,10,11,12,13,21,(22),(23),(24), 25$ & 7 \\
\hline & Total aitem & 22 \\
\hline
\end{tabular}

Catatan: angka dalam kurung (..) adalah butir yang gugur 
Hasil uji normalitas menunjukkan sebaran yang normal pada skala kecenderungan pelaku cyberbullying dengan koefisien $Z-k s=1,352$ dan $p>0,05$. Pada skala kelompok teman sebaya juga menunjukkan sebaran yang normal dengan koefisisen $Z-k s=1,293$ dan $p>0,05$. Pada skala regulasi emosi menunjukkan sebaran normal dengan koefisien $Z-k s=1,345$ dan $p>$ 0,05 . Dengan hasil uji normalitas yang demikian, maka uji asumsi normalitas untuk ketiga skala terpenuhi dengan distribusi yang normal.

Hasil uji multikolineritas dalam penelitian ini akan dilihat nilai Value Inflation Factor (VIF), dari hasil analisis variabel kelompok teman sebaya dan variabel regulasi emosi memiliki nilai $\mathrm{VIF}=3,486$ sehingga dapat dikatakan bahwa tidak terjadi multikolineritas, karena memiliki nilai VIF tidak melebihi nilai 10.

Hasil uji autokorelasi, untuk mendeteksi gejala autokorelasi, menggunakan uji Durbin-Watson (DW). Uji ini menghasilkan nilai DW hitung (d) dan nilai DW tabel ( $d L \& d v)$. Dari hasil yang sudah dihitung, maka nilai $\mathrm{DW}=1,858$, nilai $d u=1,61$, nilai $d L=1,70$ sehingga pengujian $1,61<1,858<2,3$ menunjukkan tidak ada masalah autokorelasi.

Uji heterokedastisitas adalah asumsi dalam regresi di mana varians dari residual tidak sama untuk satu pengamatan ke pengamatan yang lain. Gambar 1 adalah hasil uji heteroskedastisitas dalam penelitian.

Tampak pada Gambar 1 bahwa model penelitian tidak mempunyai gangguan heteroskedastisitas karena tidak ada pola tertentu pada grafik. Titik-titik pada grafik relatif menyebar baik di atas sumbu nol maupun di bawah sumbu nol.

Uji hipotesis mayor "ada hubungan antara kelompok teman sebaya dan regulasi emosi dengan kecenderungan menjadi pelaku cyberbullying pada remaja". Hasil analisis regresi menunjukkan bahwa variabel antara kelompok teman sebaya dan regulasi emosi secara bersama-sama memiliki hubungan yang signifikan dengan kecenderungan menjadi pelaku cyberbullying, yaitu dengan nilai $F=106,078$ dan $p<0,01$, dengan nilai Adjust $R$ Square sebesar $0,702=70,2 \%$. Berdasarkan hasil analisis tersebut, maka hipotesis mayor "ada hubungan antara kelompok teman sebaya dan regulasi emosi dengan kecen-

Scatterplot

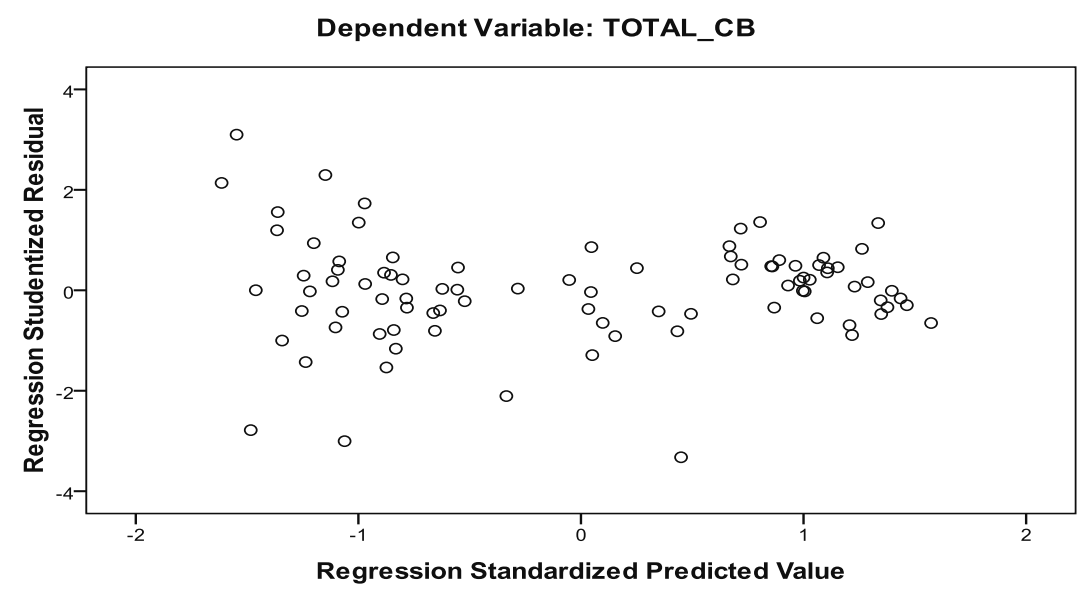

Gambar 1. Uji Heterokedastisitas 
derungan menjadi pelaku cyberbullying pada remaja" diterima.

Hipotesis minor pertama berbunyi “ada hubungan positif antara kelompok teman sebaya dengan kecenderungan menjadi pelaku cyberbullying pada remaja". Berdasarkan hasil uji analisis variabel kelompok teman sebaya dengan kecenderungan menjadi pelaku cyberbullying menunjukkan hubungan positif yang signifikan. Nilai yang diperoleh dari korelasi pearson $=0,841$ dengan $p<0,01$. Dengan demikian hipotesis yang diajukan diterima. Dalam analisis regresi berganda, terbukti bahwa variabel kelompok teman sebaya secara signifikan berpengaruh terhadap variabel kecenderungan menjadi pelaku cyberbullying, dengan nilai korelasi parsial $=0,603$ dan memiliki sumbangan efektif sebesar 0,637 .

Hipotesis minor kedua berbunyi "ada hubungan negatif antara regulasi emosi dengan kecenderungan menjadi pelaku cyberbullying pada remaja". Berdasarkan hasil uji analisis variabel regulasi emosi dengan kecenderungan menjadi pelaku cyberbullying menunjukkan hubungan negatif yang signifikan. Nilai yang diperoleh dari korelasi pearson=-0,737 dengan $p<0,01$. Dengan demikian hipotesis yang diajukan diterima. Namun, dalam analisis regersi berganda, variabel regulasi emosi tidak berpengaruh terhadap variabel kecenderungan menjadi pelaku cyberbullying karena memiliki nilai korelasi parsial $=-0,092$.

Hasil analisis tambahan menunjukkan bahwa aspek kelompok teman sebaya yang memiliki pengaruh paling besar pada variabel kecenderungan menjadi pela$\mathrm{ku}$ cyberbullying subjek penelitian adalah aspek informatif yang memberikan sumbangan sebesar $68,7 \%$. Dan aspek regulasi emosi yang memiliki pengaruh paling besar pada variabel kecenderungan menjadi pelaku cyberbullying subjek penelitian adalah aspek pemantauan yang memberikan sumbangan sebesar $48,3 \%$. Hal ini menunjukkan bahwa aspek informatif dan aspek pemantauan memiliki pengaruh paling besar dan dapat berfungsi sebagai prediktor bagi variabel kecenderungan menjadi pelaku cyberbullying.

Hasil screening pada subjek penelitian menunjukkan sebanyak 37\% subjek lakilaki banyak diminati untuk game online dan chat room, kemudian $25 \%$ untuk jejaring sosial, 21\% untuk browsing, 10\% untuk email dan $7 \%$ untuk menggunakan blog. Untuk subjek perempuan sebanyak 25\% diminati untuk jejaring sosial, kemudian $23 \%$ untuk chat room, 20\% untuk browsing, $14 \%$ untuk blog, $12 \%$ untuk email dan $6 \%$ untuk menggunaan game online. Secara keseluruhan subjek laki-laki dan perempuan menunjukkan bahwa sebanyak $25 \%$ subjek penelitian menggunakan jejaring sosial, kemudian $21 \%$ untuk penggunaan browsing, $19 \%$ untuk chat room, $12 \%$ untuk blog dan game online, dan $11 \%$ penggunaan email. Secara keseluruhan dapat dilihat, bahwa subjek penelitian baik laki-laki dan perempuan lebih banyak menggunakan jejaring sosial dan melakukan browsing. Saat ini situs jejaring sosial mendominasi trafik internet secara keseluruhan bahkan menguasai $63 \%$ trafik internet pada tahun 2009 (Parungky, 2012). Sedangkan browsing adalah aktivitas dalam mencari artikel, gambar, situs, video, audio, software dan lain-lain dalam internet untuk mendapatkan informasi yang dimaksud.

Penelitian lain yang dilakukan oleh Tarapdar dan Kellett (2011) dengan metode survei menunjukkan berbagai macam hasil tentang praktik cyberbullying di kalangan remaja Eropa, survei yang dilakukan meliputi; (1) Frekuensi cyberbullying yang dilakukan oleh remaja, ditemukan hasil $24 \%$ tidak tahu, $5 \%$ selalu, $16 \%$ sering, $17 \%$ 
kadang-kadang, dan 39\% sekali atau dua kali. Dari hasil tersebut nilai tertinggi pada frekuensi cyberbullying yang dilakukan sekali atau dua kali. Walaupun praktik cyberbullying dilakukan sekali atau dua kali, tetapi praktik ini berkesinambungan, sehingga dengan frekuensi yang jarang tetapi tetap memiliki dampak jika dilakukan secara kontinyu. (2) Bentuk-bentuk praktik cyberbullying yang dilakukan oleh pelaku cyberbullying untuk menyerang korban, ditemukan hasil 28\% email, 27\% SMS, $17 \%$ missed called, $14 \%$ menyebarkan foto dan informasi tanpa izin pemilik, 7\% mengucilkan, dan 7\% membuat website forum untuk membenci seseorang. Hasil survei menunjukkan $28 \%$ bentuk praktik cyberbullying yaitu menyerang korban melalui email yang berisi teror dan ancaman-ancaman. (3) Lokasi yang dipilih pela$\mathrm{ku}$ cyberbullying dalam melakukan praktiknya, ditemukan hasil $53 \%$ praktik dilakukan di luar sekolah, 3\% dilakukan di dalam sekolah, dan $44 \%$ dilakukan di dalam dan di luar sekolah. Dari hasil tersebut, terlihat bahwa 53\% praktik cyberbullying dilakukan di luar sekolah, hal ini memberikan rasa bebas kepada pelaku dalam melakukan tindakannya, agar terhindar dari hukuman di sekolah jika pihak sekolah telah mengetahui perbuatannya, sehingga remaja lebih memilih untuk melakukannya di luar sekolah. (4) Waktu yang dipilih untuk melakukan praktik cyberbullying, ditemukan hasil $66 \%$ dilakukan di rumah, $16 \%$ pada saat perjalanan, $12 \%$ pada saat jam makan siang, 9\% pada saat jam istirahat, dan 3\% selama jam pelajaran. Nilai survei tertinggi pada praktik cyberbullying yang dilakukan di rumah, dengan ciri khas cyberbullying yang dilakukan tanpa batas tempat dan waktu, membuat pelaku lebih merasa aman melakukannya di rumah. (5) Ratarata penggunaan teknologi informasi yang digunakan oleh remaja, ditemukan hasil
64\% digunakan untuk media sosial, 69\% penggunaan email, 70\% untuk mengirimkan pesan pendek (SMS), 73\% penggunaan internet di sekolah, $90 \%$ digunakan untuk ponsel, dan $89 \%$ penggunaan internet di luar sekolah. Penggunaan telepon seluler memiliki hasil survei yang tinggi, hal ini karena fitur yang dimiliki di ponsel mengalami kemajuan yang pesat, sehingga kemudahan dalam mengakses segala informasi sangat mudah dilakukan dan digunakan oleh kalangan remaja.

Hasil penelitian tentang praktik cyberbullying berdasarkan etnik yang dilakukan oleh Paine (2009) terhadap remaja, ditemukan hasil $15 \%$ oleh etnik China, $11 \%$ oleh etnik kulit putih Inggris, 13\% oleh etnik kulit putih Irlandia, 24\% oleh etnik kulit putih lainnya, 11\% oleh etnik asia, $7 \%$ oleh etnik kulit hitam, dan 19\% oleh etnik campuran. $24 \%$ dari etnik kulit putih lainnya adalah nilai survei tertinggi praktik cyberbullying yang dilakukan.

\section{Diskusi}

Hasil penelitian menunjukkan bahwa kelompok teman sebaya merupakan salah satu faktor yang memberikan pengaruh terhadap tinggi rendahnya kecenderungan pelaku cyberbullying. Konformitas dalam penelitian ini dapat diartikan perubahan atau penyesuaian persepsi, keyakinan dan perilaku karena adanya tuntutan maupun tekanan dari kelompok. Tuntutan tersebut dapat berupa tuntutan normatif dan informatif (Worchel \& Cooper, 1983). Remaja harus dapat menyeleksi pergaulan lingkungannya, sehingga konformitas yang terbentuk adalah konformitas yang positif, karena akan berdampak baik untuk dirinya, sebaliknya jika konformitas ini tidak bisa diartikan secara baik, maka konformitas ini akan menjadi salah satu pemicu terjadinya hal-hal yang negatif. 
Dalam hasil penelitian ini menunjukkan bahwa konformitas dapat membentuk kecenderungan menjadi pelaku cyberbullying pada remaja, dan sebaliknya. Hal ini sesuai dengan pendapat Ekowarni (1993), masa remaja merupakan masa transisi yang dapat menimbulkan krisis yang ditandai dengan kecenderungan munculnya perilaku yang menyimpang yang dalam kondisi tertentu akan menjadi perilaku yang mengganggu. Kondisi tersebut, bila disertai lingkungan yang kurang kondusif dan kepribadian yang negatif dapat menjadi pemicu timbulnya perbuatan-perbuatan negatif yang melanggar aturan dan norma yang ada di masyarakat bahkan melanggar hukum.

Variabel kelompok teman sebaya memiliki sumbangan besar terhadap variabel kecenderungan menjadi pelaku cyberbullying adalah sebesar $63,7 \%$, hasil ini sesuai dengan hasil penelitian yang dilakukan oleh salah satu media online Ipsos, yang meneliti secara online di 24 negara dengan total responden 18.867 warga, dimana salah satu hasilnya adalah negara Indonesia menduduki persentase yang besar dan urutan pertama (53\%), dimana cyberbullying terjadi dalam komunitas teman sebaya mereka (Gottfried, 2012). Sisanya sebesar $36,3 \%$ merupakan pengaruh dari faktor lain, baik itu berasal dari dalam maupun dari luar diri subjek penelitian yang memungkinkan memberikan pengaruh terhadap kecenderungan menjadi pelaku cyberbullying pada remaja.

Keterkaitan tentang praktik cyberbullying yang merupakan bentuk agresi, memiliki penurunan rasa empati dan kemampuan untuk memahami perasaan orang lain. Seorang pelaku cyberbullying akan menjadi takut menjadi korban dari cyberbullying, karena praktik cyberbullying adalah proses agresi berbentuk lingkaran yang tidak terputus. Berada di dalam kelompok teman sebaya merupakan latihan seseorang dalam membangun rasa empati terhadap orang lain dan belajar menyikapi ketika terjadi proses agresi. Ketika perilaku agresi memiliki dampak yang merugikan, maka perlu diberikan pelatihan empati untuk bisa mengatur kembali emosinya (Steflgen, Konig, Pfetsch, \& Melzer, 2011).

Cyberbullying berasal dari praktik bullying yang berkelanjutan, dan lingkungan sekolah adalah tempat berkembangnya praktik bullying. Sehingga dengan adanya lingkungan sekolah yang tidak sehat, teman sebaya yang tidak bersahabat, dan pengaturan emosi yang minim membuat perkembangan praktik bullying semakin meningkat menjadi praktik cyberbullying di kalangan remaja. Sehingga diperlukan titik fokus pada penanganan praktik bullying di sekolah sebelum menangani cyberbullying, karena lingkungan sekolah adalah lingkungan perkembangan sosial remaja dengan teman sebayanya, dan remaja banyak menghabiskan waktunya dengan teman sebaya (Lester, Cross, \& Shaw, 2012).

Keluarga dan teman sebaya merupakan lingkungan dalam konteks relasional, sehingga baik atau buruknya dampak yang diterima dalam berhubungan akan menjadi stimulus bagaimana seorang remaja bersikap. Kontinuitas yang kuat antara bullying dan cyberbullying diakibatkan pengawasan dari orangtua yang minim, sehingga rasa kesepian yang di alami remaja, akan dihabiskan bersama teman sebayanya. Remaja yang kesepian menganggap bahwa pihak pertama yang melakukan bullying atas diri mereka adalah orangtua mereka sendiri, sehingga hal tersebut menjadikan remaja lebih nyaman berada dalam lingkungan teman sebaya (Guarini, Passini, Melotti, \& Brighi, 2012). 
Hasil analisis juga membuktikan bahwa regulasi emosi berkorelasi secara negatif dengan kecenderungan pelaku cyberbullying, namun tidak berpengaruh terhadap kecenderungan pelaku cyberbullying pada remaja. Terdapat faktorfaktor lain di luar regulasi emosi yang memungkinkan berpengaruh terhadap kecenderungan pelaku cyberbullying pada remaja seperti faktor pengabaian dari orangtua, pola asuh orangtua, kekerasan pada anak, dan obat-obatan yang terlibat dalam cyberbullying. Sebagaimana halnya dengan yang dikemukakan oleh Kostiuk dan Gregory (2002) dalam penelitiannya yang menemukan bahwa kombinasi dari kelekatan yang tidak kuat dan perilakuperilaku pola asuh orangtua dapat menyebabkan anak mengalami ketidakmampuan meregulasi emosi serta terlibat dalam perilaku-perilaku menganggu. Adanya kemampuan mengelola emosi yang baik dapat membantu seseorang dalam mengontrol dirinya untuk tidak terlibat dalam perilaku yang negatif terutama ketika sedang mengalami masalah dan tekanan. Ini berarti, kemampuan dalam meregulasi emosi mempengaruhi kemampuan seseorang dalam mengontrol dirinya sehingga dengan adanya kemampuan mengontrol diri yang baik dapat membuat seseorang mengarahkan perilakunya dengan baik dan terhindar dari praktik cyberbullying.

Regulasi emosi berperan dalam pembentukan kompetensi sosial seseorang dalam menjalankan kehidupannya, karena manusia adalah mahkluk sosial yang saling membutuhkan orang lain. Praktik cyberbullying merupakan proses belajar sosial yang maladaftif, sehingga terjadi intimidasi nonfisik (verbal dan relasional). Alasan yang mendasari praktik cyberbullying terjadi dikarenakan karena keinginan untuk intimidasi, konflik, peman- tauan orangtua yang minim, permusuhan, gejala depresi, rasa empati yang kurang, dan pengaruh napza. Dari alasan-alasan tersebut membentuk pengaturan emosi yang rendah, sehingga mempengaruhi kompetensi sosialnya dalam berhubungan dengan orang lain (Low \& Esplage, 2013).

Cyberbullying merupakan bentuk pelanggaran, baik korban dan pelaku mendapatkan masalah psikososial, afektif dan akademik. Banyaknya kasus bunuh diri yang dilakukan dipicu oleh banyaknya pengalaman cyberbullying. Dampak dari cyberbullying bergantung pada frekuensi praktik tersebut, sehingga efeknya sudah menjadi suatu permasalahan serius dalam kesehatan mental masyarakat dan diperlukan pengelolaan emosi secara baik dalam mengontrol, pemantauan stimulus-stimulus yang diterima dan penilaian atas setiap peristiwa yang dialami (Tokunaga, 2010).

\section{Kesimpulan}

Kecenderungan menjadi pelaku cyberbullying berhubungan secara positif dengan kelompok teman sebaya, semakin tinggi kelompok teman sebaya maka semakin tinggi pula kecenderunan menjadi pelaku cyberbullying, kelompok teman sebaya memiliki pengaruh terhadap kecenderungan menjadi pelaku cyberbullying. Kemudian kecenderungan menjadi pelaku cyberbullying berhubungan secara negatif dengan regulasi emosi, semakin rendah regulasi emosi maka semakin tinggi kecenderungan menjadi pelaku cyberbullying atau semakin tinggi regulasi emosi maka semakin rendah kecenderungan menjadi pelaku cyberbullying, namun regulasi emosi tidak terbukti berpengaruh terhadap kecenderungan menjadi pelaku cyberbullying. 


\section{Saran}

Subjek penelitian diharapkan dapat memahami kelompok teman sebaya merupakan salah satu variabel yang dapat meningkatkan seseorang untuk menjadi pelaku cyberbullying. Sehingga remaja diharapkan harus berhati-hati dalam berinteraksi dengan lingkungannya, karena kelompok teman sebaya dapat mempengaruhi seseorang menjadi pelaku cyberbullying.

Sekolah sebaiknya lebih memberikan pandangan bagaimana pergaulan yang baik dan positif dalam lingkungan siswa. Dari hasil penelitian, subjek laki-laki lebih banyak bermain game online dan untuk subjek perempuan lebih banyak menggunakan jejaring sosial, sehingga diharapkan pihak sekolah dapat memberikan pandangan bagaimana menggunakan internet dengan sehat.

Membuat program Embodied Conversational Agent (ECA) milik Zwaan, Dignum, dan Jonker (2010) yaitu sebuah program bagi pelaku atau pun korban yang mengalami praktik cyberbullying dengan bantuan seseorang teman sebayanya yang disebut dengan agent. Agen tersebut dilatih untuk bisa mengatasi berbagai macam bentuk emosi negatif dari sebab dan akibat praktik cyberbullying yang berdampak pada masa depan pelaku dan korban. Terdapat tiga tahapan yang dilakukan oleh agen, yaitu; (a) Komunikasi keadaan sosial; (b) Informasi tentang situasi; (c) Memberikan saran praktis tentang bagaimana menangani permasalahan. Dalam program ini diharapkan dapat meningkatkan rasa empati kepada teman sebaya.

\section{Kepustakaan}

Agatson, P. W., Kowalski, R., \& Limber, S. (2007). Students' perspectives on cyber bullying. Journal of Adolescent Health, 41(6), S59-S60.

Belsey, B. (2007). 'Always on? always aware!'. Diunduh dari: http://www. cyberbullying.org/pdf/Cyberbullying_ Information.pdf tanggal 30 April 2007.

Beran, T., \& Li, Q. (2005). Cyber-harassment: a study of a new method for an old behavior. Journal Educational Computing Research, 32(3), 265-277.

Berthold, K. A., \& Hoover, J. H. (2000). Correlates of bullying and victimization among intermediate students in the midwestern USA. Journal of School Psychology Internatioal, 21, 65-78.

Brehm, S. S., \& Kassin, S. M. (1993). Social psychology second edition. Boston: Houghton Mifflin Company.

Campfield, D. C. (2006). Cyberbullying and victimization: psychosocial characteristics of bullies, victims and bully/Victims (Disertasi). The University of Montana, Montana.

Cochrane, K. R. (2008). Exploring cyberbullying in saskatchewan (Tesis unpublished). The University of Saskatchewan. Sasktoon.

Crick, N. R., \& Gropeter, J. K. (1995). Relational aggression, gender, and social psychological adjustment. Child Development, 66, 710-722.

David-Ferdon, C., \& Hertz, M. F. (2007). Youth violence and electronic media: similar behavior, different venues? (special issue). Journal of Adolescent Health, 41(6), S1-S68. 
Ekowarni, E. (1993). Kenakalan remaja: suatu tinjauan psikologi. Buletin Psiko$\log i, 2,24-27$.

Ericson, N. (2001). Addressing the problem of juvenile bullying. OJJDP Fact Sheet June 2001 \#27. U.S. Department of Justice

Finkelhor, D., Mitchell, K. J., \& Wolak, J. (2006, Agustus 20). Online victimization: a report on the nation's youth. Diakses dari: http://www.unh.edu/ crcc/Youth_Internet_info_page.html

Garber, J., \& Dodge, K. A. (2004). The development of emotion regulation and dysregulation. New York: Cambridge University Press

Gottfried, K. (2012). One in Ten (12\%) Parents online, around the world say their child has been cyberbullied, $24 \%$ say they know of a child who has experienced same in their community. Ipsos Global Public Affairs.

Greenberg, M. A., \& Stone, A. A. (1992). Emotional disclosure about traumas and its relation to health: effect of previous disclosure and trauma severity. Journal of Personality and Social Psychology, 63(1), 75-84.

Guarini, A., Passini, S., Melotti, G., \& Brighi, A. (2012). Risk and Protective Factors on Perpetration of Bullying and Cyberbullying. Adam Mickiewicz : Bologna.

Kostiuk, L. M., \& Gregory T. F. (2002). Understanding of emotions and emotion regulation in adolescent females with conduct problems: a qualitatif analysis. The Qualitative Reports, 7(7).

Lester, L., Cross D., Shaw, T. (2012). Problem Behaviours, Traditional Bullying and Cyberbullying Among Adolescents: Longitudinal Analyse. Edith Cowan University Research Online. Cowan University: Australia.
Li, Q. (2007). New bottle but old wine: a research of cyberbullying in schools. Computers in Human Behavior, 23(4), 1777-1791.

Lines, E. (2007). Cyber-bullying: our kids' new reality a kids help pone research study of kids online. Diunduh dari: http://www.kidshelpphone.ca/beingth ereforkids/newsroom/images/CyberB ullying_Report_2007_full.pdf tanggal 25 September 2007.

Low, S., \& Espelage, D. (2013). Differentiating Cyberbullying Perpetration From Non Physical Bullying: Communalities Across Race, Individual, and Family Predictors. Psychology of Violence, 3(1), 39-52.

Mendolia, M., \& Kleck, R. (1993). Effect of talking about a stressful event on arousal: Does What we talk abaout make a difference. Journal of personality and social psychology, 64(2), 283-292.

Nansel, T. R., Overpeck, M., Pilla, R. S., Ruan, W. J., Simons-Morton, B., \& Scheidt, P. (2001). Journal of American Medical Association, 285(16), 2094-2096.

Olweus, D. (1994). Annotation: bullying at school: basic facts and effects of a school based intervention program. Journal of Child Psychology and Psychiatry, 35(7), 1171-1190.

Paine, T. (2009). Virtual Violence : Protecting Children From Cyberbullying. Rochester House, London.

Parungky, O. (2012). Mengapa situs jejaring sosial hampir tidak pernah mengalami server down?. Diunduh dari: http://ofy. parungky.web.ugm.ac.id/wpcontent/uploads/SO-Jejaring-sosial.pdf tanggal 26 Maret 2012.

Prinstein, M. J., Boergers, J., \& Vernberg, E.M. (2001). Overt and relational aggression in adolescents: socialpsychological adjustment of aggres- 
sors and victims. Journal of Clinical Child Psychology, 30(4), 479-491.

Raskauskas, J., \& Stoltz, A. D. (2007). Involvement in traditional and electronic bullying among adolescents. Developmental Psychology, 43(3), 564575.

Steflgen, G., Konig, A., Pfetsch, J., \& Melzer A. (2011). Are Cyberbullies Less Empathic? Adolescent's Cyberbullying Behavior and Empathic Responsiveness. Cyberpsychology, Behavior, and Social Networking, 14(11).

Stephan, C. W., \& Stephan, W. G. (1985). Two social psychologies. Ill: The Doriety Press.

Stroebe, M., Stroebe, W., Schut, H., Zech, E., \& Bout, J.V. (2002). Does disclosure of emotions facilitate recovery from bereavement? Evidence form two prospective studies. Journal of consulting and clinical psychology, 70(1), 169178.

Tarapdar, S., \& Kellett, M. (2011). Young People's Voices on Cyberbullying : What can age comparisons tell us ?. Diana Award, London.

Tokunaga, R. S. (2010) Following You Home From School: A Critical Review and Synthesis of Research in Cyberbullying Victimization. Journal of Computer in Human Behavior, 26, 277-287.

Wahyu, F. A. (2012). Premanisme via gadget bikin remaja bunuh diri. Detikinet.
Diunduh dari: http://inet.detik.com/ $\mathrm{read} / 2007 / 11 / 13 / 124743 / 851873 / 398 / \mathrm{pr}$ emanisme-via-gadget-bikin-remajabunuh-diri tanggal 17 April 2012.

Willliams, J. L. (2012) Teens, Sexts, \& Cyberspace: The Constitutional Implications of Current Sexting \& Cyberbullying Laws. William $\mathcal{E}$ Mary Bill of Right Journal, 20(3).

Williams, K. D., Cheung, C. K. T., \& Choi, W. (2000). Cyberostracism: effects of being ignored over the internet. Journal of Personality and Social Psychology, 79(5), 748-762.

Worchel, S., \& Cooper, J. (1983). Understanding social psychology. Ill: The Dorsey Press

Ybarra, M. L., Alexander, C., \& Mitchell, K.J. (2005). Depressive symptomatology, youth Internet use, and online interactions: A national survei. Journal of Adolescent Health, 36, 9-18.

Ybarra, M., \& Mitchell, K. (2004a). Online aggressor/targets, aggressors, and targets: acomparison of associated youth characteristics. Journal of Child Psychology and Psychiatry, 45, 1308-131.

Zwaan, J. V. D., Dignum V., \& Jonker C. (2010). Simulating Peer Support For Victims of Cyberbullying. Delfit Universitu of Technology, Netherlands. 